Int. J. Dev. Biol. 53: 1013-1022 (2009)

doi: $10.1387 / \mathrm{ijdb} .082726 \mathrm{cj}$

\title{
A novel role of the glial fate determinant glial cells missing in hematopoiesis
}

\author{
CÉCILE JACQUES, LAURENT SOUSTELLE\#, ISTVÁN NAGY\#\#, CÉLINE DIEBOLD and ANGELA GIANGRANDE* \\ Institut de Génétique et de Biologie Moléculaire et Cellulaire, CNRS/INSERM/ULP, C.U. de Strasbourg, France
}

\begin{abstract}
Glial cell deficient/Glial cells missing (Glide/Gcm) transcription factor is expressed in all glial precursors of the Drosophila embryo. $\mathbf{G c m}$ is necessary and sufficient to induce glial differentiation but also plays a role in other cell types, by interacting with specific factors. To find potential partners of $\mathrm{Gcm}$ which trigger these other pathways, we performed a yeast two-hybrid screen and identified dpias, a gene involved in post-embryonic hematopoiesis. dpias larvae show melanotic tumors due to excess of lamellocytes, a hemocyte lineage that is involved in non-self recognition. We here show that blocking $\mathbf{G c m}$ activity also triggers melanotic tumors and that gcm interacts genetically with dpias. Moreover, the members of the Janus Kinase (JAK)/ Signal Transducer and Activator of Transcription (STAT) pathway, which are known for their role in the vertebrate and invertebrate immune system and are required for dpias-dependent tumor formation, act downstream of $\mathrm{Gcm}$. Altogether, this study identifies an unpredicted role of $\mathrm{Gcm}$, dictated by its cofactor dpias, allowing $\mathrm{Gcm}$ to act in a specific pathway. Together with the recent finding that glia act as scavengers during development and in pathological conditions, our data open new perspectives onto the cellular and molecular pathways involved in non-self recognition within and outside the nervous system.
\end{abstract}

KEY WORDS: Drosophila melanogaster, glide/gcm, dpias, JAK/STAT, hematopoiesis

\section{Introduction}

Glial cell deficient/glial cells missing (glide/gcm), referred to throughout the text as $\mathrm{gcm}$, codes for a transcription factor that is expressed in embryonic glial precursors (Hosoya et al., 1995; Jones et al., 1995; Vincent et al., 1996). Lack of gcmleads to loss of most lateral glia, which transform into neurons, while ectopic gcm pan-neural expression leads to differentiation of supernumerary glia at the expense of neurons (Akiyama-Oda et al., 1998; Bernardoni et al., 1998; Hosoya et al., 1995; Jones et al., 1995; Vincent et al., 1996), for review (Soustelle and Giangrande, 2007a). While gcm2, the homolog of $\mathrm{gcm}$, is also expressed in embryonic glial precursors, its mutation does not induce detectable glial defects, likely due to its very low levels of expression (Alfonso and Jones, 2002; Kammerer and Giangrande, 2001). Expression of the gcmgene as well as RNA and protein processing are tightly regulated (Akiyama et al., 1996; Akiyama-Oda et al., 1999; Bernardoni et al., 1999; Jones, 2005; Kammerer and Giangrande, 2001; Miller et al., 1998; Ragone et al., 2003;
Soustelle et al., 2008).

In addition to these transcriptional and post-transcriptional regulatory mechanisms, the activity of Gcm is mediated by cellular context (Miller et al., 1998; Ragone et al., 2003). A cellspecific factor, Huckebein, interacts directly with $\mathrm{Gcm}$ and triggers $\mathrm{Gcm}$ autoregulation in the thoracic neuroblast lineage 1-1 (NBT1-1). Such protein-protein interaction is necessary to promote glial differentiation and specify the sub-perineural glia fate in that lineage (De laco et al., 2006). Finally, while $\mathrm{gcm}$ is necessary and sufficient to induce embryonic glia, it is clear that this gene is involved in other developmental pathways as well. $\mathrm{gcm}$ is expressed and required in embryonic hemocytes (Alfonso and Jones, 2002; Bataille etal., 2005; Bernardoni etal., 1997) and tendon cells (Soustelle et al., 2004); it is also necessary in specific neuronal and glial lineages of the post-embryonic nervous system

\footnotetext{
Abbreviations used in this paper: dpias, Drosophila protein inhibitor of activated STAT; gcm, glial cells missing; JAK, janus kinase; STAT, signal transducer and activator of transcription.
}

\footnotetext{
*Address correspondence to: Angela Giangrande. IGBMC, BP 10142, 67404 IIIkirch, Strasbourg, France. e-mail: angela@titus.u-strasbg.fr

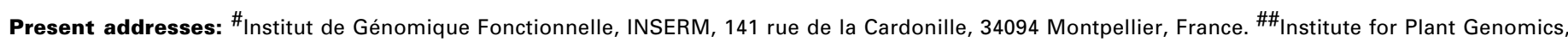
Human Biotechnology and Bioenergy, Bay Zoltan Foundation for Applied Research, Derkovits fasor 2, 6726 Szeged, Hungary
} 
(Chotard etal., 2005; Soustelle and Giangrande, 2007b; Soustelle et al., 2007; Yoshida et al., 2005). Importantly, gcm-dependent differentiation of these cell types relies on the activation of mutually exclusive molecular pathways (for review (Soustelle and Giangrande, 2007a).

All these data indicate that $\mathrm{Gcm}$ activates distinct target genes upon interaction with cell/tissue-specific cofactors to induce distinct differentiation programs.

We here identify several potential partners of $\mathrm{Gcm}$ by a yeast two-hybrid approach. Surprisingly, one such partner is coded by dpias, a gene required in post-embryonic hematopoiesis, a process that has not been so far described as being Gcm-dependent. We also show that blocking Gcm function in tissues of the postembryonic immune system triggers a melanotic tumor phenotype, similar to what is observed in dpias mutant larvae (Betz et al., 2001; Hari et al., 2001). Altogether, this study identifies dpias as a cofactor of $\mathrm{Gcm}$ in the cascade that maintains post-embryonic blood cell homeostasis. In addition, we show that members of the JAK/STAT signaling cascade, which are known for their role in post-embryonic hematopoiesis and rely on dpias, act downstream of $\mathrm{gcm}$. These data allow us to identify a novel $\mathrm{Gcm}$ pathway and cofactor acting in such pathway. Finally, our study highlights common features between glia and hemocytes in Drosophila, in line with recent data demonstrating that glia play a scavenger role in physiological and pathological conditions (Awasaki et al., 2006; Freeman et al., 2003; MacDonald et al., 2006). Interestingly, mammalian microglia display highly mobile processes that are constantly screening the nervous system and display a macrophage function (Hanisch and Kettenmann, 2007). Altogether, these data lead to the speculation that invertebrate glia and/or hemocytes may be at the origin of microglia, the scavenger cells of the mammalian nervous system.

The present study was designed to gain insight into the mode of action of the Gcm transcription factor by identifying new cofactors. Gcm is indeed well known to have specific functions dictated by the presence of cell-specific cofactors. Upon performing a yeast twohybrid screen we identified dpias (Protein Inhibitor of Activated STAT), a protein that controls post-embryonic hematopoiesis. This allowed us to reveal an upredicted role of $\mathrm{Gcm}$ and a novel molecular cascade.

\section{Results}

\section{Identification of Gcm cofactors by yeast two-hybrid screen}

$\mathrm{gcm}$ codes for a transcription factor of 504 amino-acids carrying several motifs including a DNA binding domain (DBD), a nuclear localization signal (NLS), a PEST domain and an activation domain (AD) (Fig.1A). To gain insights into the $\mathrm{Gcm}$ mode of action, we performed a yeast two-hybrid screen. To determine the optimal construct for the screen, we removed different domains of Gcm and used the deleted constructs for autoactivation tests in yeasts. Strikingly, we found that a fragment of the $\mathrm{C}$-terminal part of $\mathrm{Gcm}$ (aa261-aa421) leads to strong autoactivation, even though the $A D$ is not present in this construct (data not shown). In contrast, we did not detect autoactivation upon using a fragment containing the N-terminal part of Gcm, which includes the DBD, the NLS as well as the PEST domain (aa1-aa261) and thus used this construct for the screen (Fig.1A).

Twelve partners were identified (Fig.1B). Amongst them,
Karyopherin- $\alpha 1$ and Pendulin (also called Importin- $\alpha 1$ and Importin- $\alpha 2$, respectively) are known to transport NLS carrying transcription factors from the cytoplasm to the nucleus (Goldfarb et al., 2004). Accordingly, we found that the interaction between Gcm and Karyopherin- $\alpha 1$ or Pendulin needs the NLS domain of Gcm (Fig.1B).

Another candidate identified in our screen is Uba2 (also called Smt3 activating enzyme 2), which requires the PEST domain of Gcm to interact (Fig.1B). uba2 codes for a SUMO-1 conjugation enzyme playing a role in sumoylation, a process that modulates the activity of many proteins (Zhao, 2007). In line with our results, GCMa, the human ortholog of fly $\mathrm{Gcm}$, is also a target of the sumoylation machinery (Chou et al., 2007). In their study, the authors showed that GCMa-mediated transcriptional activation is repressed by sumoylation, due to a decreased DNA binding activity of GCMa, suggesting that this regulation also exists in flies.

Strikingly, one of the candidates identified during the screen codes for dpias (also called Su(var)2-10 or Zimp), a nuclear protein that is required in hematopoiesis in the Drosophila larva. Because $\mathrm{gcm}$ is known to play a role during embryonic hematopoiesis, we focused our attention on this particular candidate.

In order to confirm the interaction between Gcm and dpias, we performed immunoprecipitation experiments from cytoplasmic extracts of S2 cells transiently overexpressing a Flag-tagged version of $\mathrm{Gcm}$ and a HA-tagged version of dpias. Then, we determined whether anti-Flag antibody coprecipitates the HAtagged dpias protein. As shown in Fig.1C (top panel), Flag-Gcm is expressed after transfection of $\mathrm{S} 2$ cells and efficiently precipitated. Importantly, HA-dpias is also detected in transfected cells and in the Flag-precipitated proteins (Fig.1C, bottom panel) calling for Gcm - dpias interaction.

\section{gcm interacts genetically with dpias}

The embryonic hematopoietic anlagen produces two types of hemocytes: the crystal cells, which depend on the RUNX factor Lozenge for their differentiation (Lebestky et al., 2000), and the plasmatocytes/macrophages, which are under the control of $\mathrm{gcm}$ genes (Alfonso and Jones, 2002; Bernardoni etal., 1997). At postembryonic stages, however, the production of hemocytes (crystal cells and plasmatocytes/macrophages) resides in a specialized

TABLE 1

\section{GENETIC INTERACTION BETWEEN GCM AND DPIAS}

\begin{tabular}{|c|c|}
\hline Genotype & Presence of melanotic tumors \\
\hline dpias $^{1} /$ dpias $^{1}$ & Embryonic lethal \\
\hline $\mathrm{gcm}^{26} / \mathrm{gcm}^{26}$ & Embryonic lethal \\
\hline gcm-gal4 / gcm-gal4 & NO \\
\hline gcm-gal4 / gcm ${ }^{26}$ & NO \\
\hline gcm-gal4 / dpias ${ }^{1}$ & NO \\
\hline dpias $^{1}, \mathrm{gcm}^{26} /$ dpias $^{1}, \mathrm{gcm}^{26}$ & Embryonic lethal \\
\hline gcm-gal4 / dpias ${ }^{1}, \mathrm{gcm}^{26}$ & YES L2/L3 (1/200) \\
\hline
\end{tabular}

The genotypes of analysed larvae are described in the left column. Right column describes the observed phenotypes, note that $d p^{2} \mathrm{~s}^{1}, \mathrm{gcm}^{26}$ and $d \mathrm{pias}^{1}, \mathrm{gcm}^{26}$ homozygous animals die at embryonic stages. Removing one copy of dpias in combination with a $\mathrm{gcm}$ hypomorphic allele $\left(\mathrm{gcm}-\mathrm{ga} / 4 / \mathrm{dpias}^{\prime}\right)$ did not produce any larval melanotic tumor. In contrast, tumors were detected in animal lacking one copy of $\mathrm{gcm}$ and dpias in combination with a $\mathrm{gcm}$ hypomorphic allele $(\mathrm{g} \mathrm{cm}$ gal4/dpias ${ }^{1}, \mathrm{gcm}^{2}$ ), indicating that $\mathrm{gcm}$ and dpias interact genetically. All experiments were performed at $29^{\circ} \mathrm{C}$. 
hematopoietic organ, the lymph gland, which produces an additional type of hemocytes, the lamellocytes, in response to parasitism (Sorrentino et al., 2002). Prohemocytes of the lymph gland, the precursors of hemocytes, start hyperproliferating and produce lamellocytes, which aggregate in high number together with circulating hemocytes (Lanot et al., 2001; Meister and Lagueux, 2003). Lamellocytes act in concert with crystal cells and plasmatocytes/macrophages in the cellular immune response by encapsulating pathogens that invade the larval hemolymph. This process, which leads to the formation of melanotic tumors that are clearly identifiable by their black color, also takes place when blood cell homeostasis is altered in mutant conditions. For example, it is known that overactivation of the JAK/STAT signaling activity is sufficient to induce massive lamellocyte differentiation (Harrison et al., 1995; Luo et al., 1995; Zettervall et al., 2004). In Drosophila, dpias owns its name to its role and represents the unique member of the PIAS family, known to act negatively on STAT transcription factors (Betz et al., 2001). Loss of function of dpias gene is known to trigger lamellocyte differentiation and melanotic tumor formation (Betz et al., 2001; Hari et al., 2001).

To show that $\mathrm{gcm}$ and dpias interact in vivo, we analyzed animals that loose the two genes simultaneously by constructing a recombinant line carrying a null allele of $\mathrm{gcm}\left(\mathrm{gcm}^{26}\right)$ with $\mathrm{dpias}^{1}$ mutation. Since the dpias ${ }^{1}$ and the $g \mathrm{~cm}^{26}$ homozygous animals die at embryonic stage, we crossed this recombinant line with a weak $\mathrm{gcm}$ hypomorphic allele, $\mathrm{gcm}$-gal4 (Soustelle and Giangrande, 2007b). We never found melanotic tumors in original dpias $^{1}, \mathrm{gcm}^{26}$, and $\mathrm{gcm}$-ga/4 lines nor in the recombinant $\mathrm{gcm}^{26}$, dpias ${ }^{1}$ (see Table 1). In contrast, we did observe melanotic tumors in larvae lacking one copy of dpias and more than one copy of $\mathrm{gcm}$ (transheterozygous animals carrying $\mathrm{gcm}^{26}$ in combination with $\mathrm{gcm}-\mathrm{ga} / 4$ ). These genetic data confirm that $\mathrm{gcmand}$ dpias act in the same molecular pathway.

\section{Post-embryonic Gcm loss of function causes larval death and melanotic tumors as observed in dpias mutant}

To elucidate the role of $\mathrm{Gcm}$ in post-embryonic hematopoiesis we decided to use a time- and tissue-specific mutant allele.

A

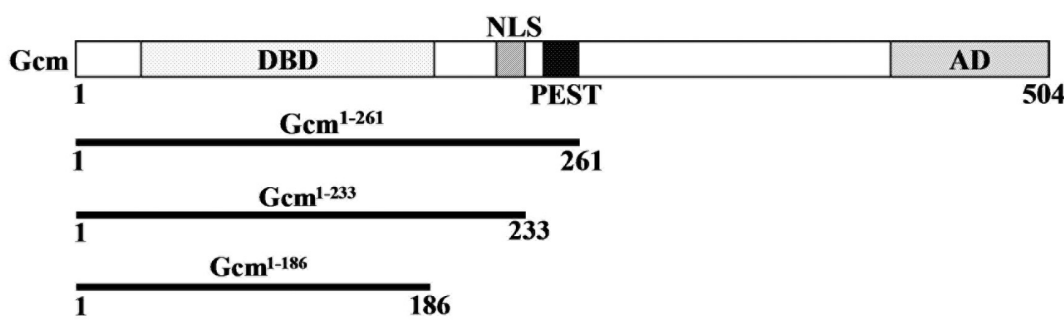

B

\begin{tabular}{|c|c|c|c|c|}
\hline Candidates & Product/Function & $\mathrm{Gcm}^{1-261}$ & $\mathrm{Gcm}^{1-233}$ & $\mathrm{Gcm}^{1-186}$ \\
\hline CG1244 & Predicted transcription factor, unknown function ${ }^{(1)}$ & +++ & +++ & ++ \\
\hline CG2199 & Predicted transcription factor, unknown function ${ }^{(1)}$ & +++ & +++ & +t+ \\
\hline CG2926 & Predicted transcription factor, unknown function ${ }^{(1)}$ & +++ & + & - \\
\hline CG9715 & Predicted transcription factor, unknown function ${ }^{(1)}$ & +++ & ++ & + \\
\hline Charlatan & Transcription factor, nervous system development ${ }^{(2)}$ & +++ & +++ & +++ \\
\hline dpias & DNA binding protein, negative regulation of JAK-STAT pathway ${ }^{(3)}$ & +++ & $+1-$ & $+1-$ \\
\hline Karyopherin- $\alpha 1$ & Carricr protein, protcin import into nuclcus ${ }^{(4)}$ & +++ & +++ & - \\
\hline Mical & Actin binding protein, axon guidance ${ }^{(5)}$ & +++ & + & $+/-$ \\
\hline Pendulin & Carrier protein, protein import into nucleus ${ }^{(6)}$ & +++ & +++ & - \\
\hline Pleiohomeotic like & Transcription factor, transcription regulator activity ${ }^{(7)}$ & +++ & +++ & + \\
\hline Slik 1 & Receptor signaling protein, regulation of protein localization ${ }^{(8)}$ & +++ & - & - \\
\hline Uba2 & Ubiquitin activating enzyme, sumoylation ${ }^{(9)}$ & +++ & $+1-$ & $+1-$ \\
\hline
\end{tabular}

C

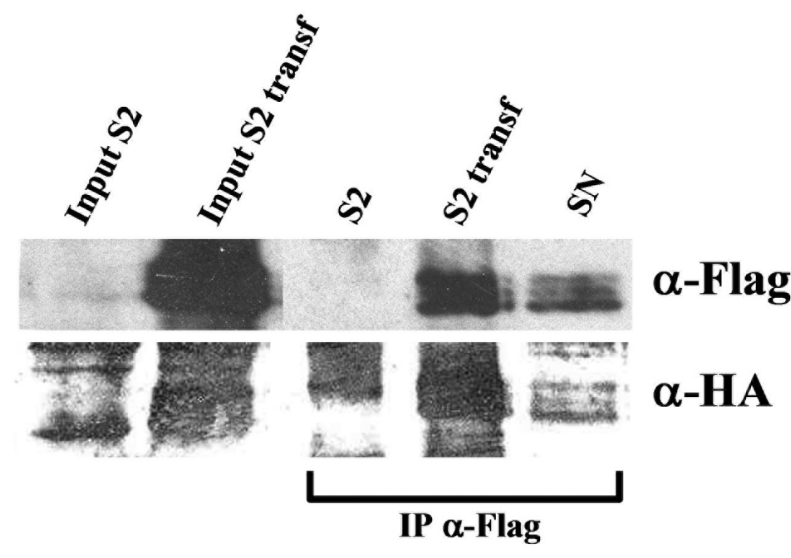

Fig. 1. Gcm and its putative cofactors. (A) Schematic representation of $\mathrm{Gcm}$ transcription factor structure. DBD, DNA-binding domain; NLS, nuclear localization signal; PEST, rapid turnover signature; $A D$, activation domain. Black lines indicate the different baits used in the screen to identify the interaction domain. (B) Table indicating the putative cofactors of Gcm identified in this study, their predicted/demonstrated function, as well as the strength of interaction between baits and putatives cofactors (indicated by plus and minus signs). Note that interaction strength is not an absolute value and cannot therefore be used to compare $\mathrm{Gcm}$ affinity for different candidates. (1) Flybase: http://flybase.bio.indiana.edu/, (2) (Escudero et al., 2005), (3) (Betz et al., 2001; Hari et al., 2001; Mohr and Boswell, 1999), (4) and (6) (Goldfarb et al., 2004), (5) (Beuchle et al., 2007; Terman et al., 2002), (7) (Brown et al., 2003; Wang et al., 2004), (8) (Hipfner and Cohen, 2003; Hipfner et al., 2004), (9) (Donaghue et al., 2001). (C) $\mathrm{Gcm}$ interacts with dpias. Drosophila $S 2$ cells were transiently transfected with expression plasmids encoding Flag-tagged $\mathrm{Gcm}$ in combination with HA-tagged dpias. Whole-cell extracts were subjected to immunoprecipitation (IP) with anti-Flag (indicated by IP $\alpha$-Flag). The samples were subjected to SDS-PAGE, and Western blots were probed by using the anti-Flag (top panel) or the anti-HA (bottom panel) antibody. Input indicates sample of $S 2$ cell extracts prior to immunoprecipitation (Input S2 for untransfected cells, Input S2 transf for transfected S2 cells). S2, S2 transf and SN indicate the product of IP from untransfected S2 cells, transfected S2 cells, and the supernatant from transfected S2 cells, respectively. As seen on top panel, Flagtagged $\mathrm{Gcm}$ is detected as a triplet in transfected S2 cells (Input S2 transf) and efficiently immunoprecipitated (S2 transf). HA-dpias is expressed in transfected S2 cells (Input S2 transf) and immunoprecipitated by anti-Flag (S2 transf). Note the presence of a weak signal in the SN for both Gcm-Flag and dpias-HA. 

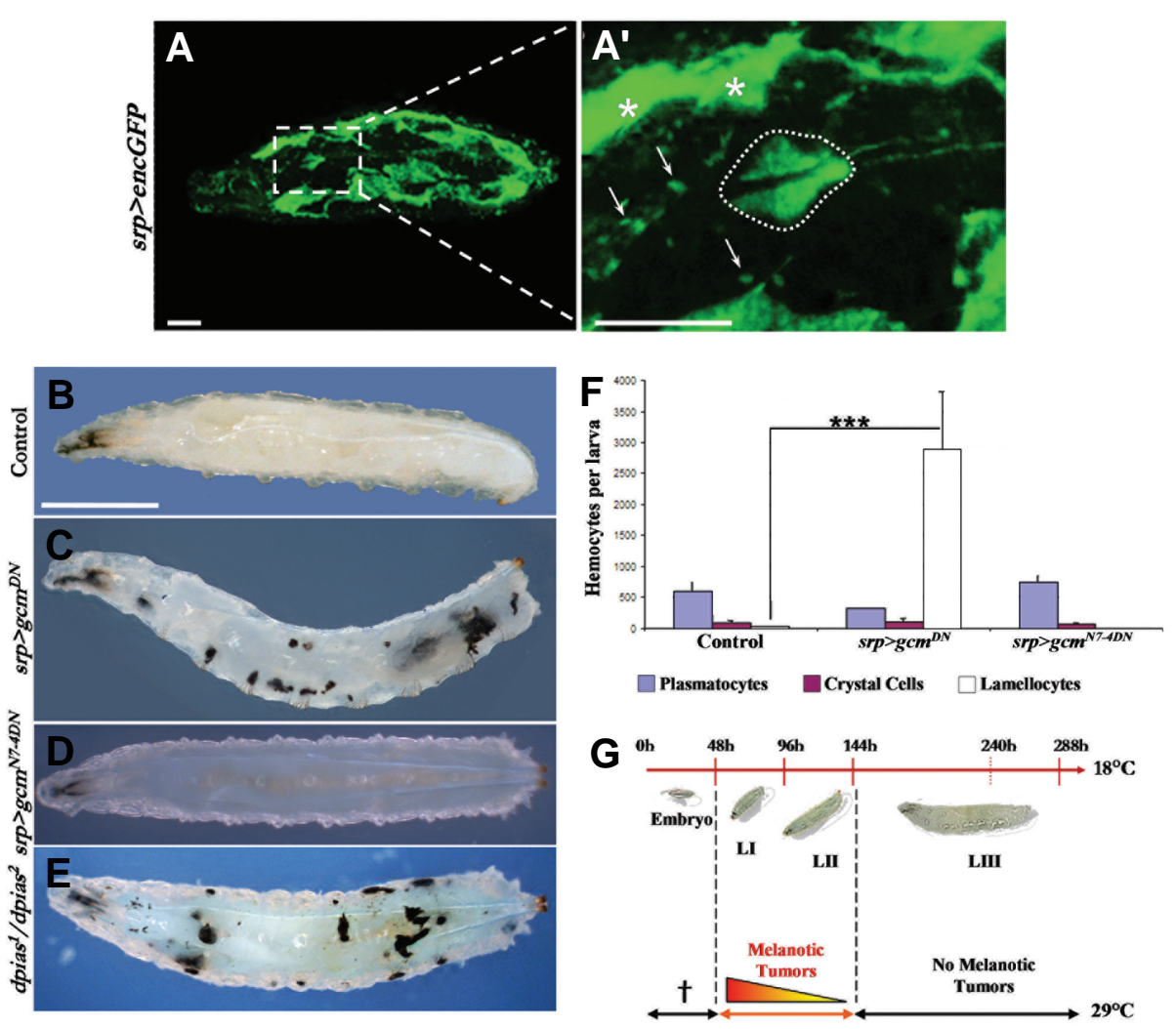

Fig. 2. gcm or dpias loss of function induces melanotic tumors. $\left(\mathbf{A}, \mathbf{A}^{\prime}\right)$ serpent-gal4,UASencGFP (srp>encGFP) first instar larva. (A') shows the region delimited in the dashed box in (A). GFP is present in the lymph gland (encircled dotted line), in all hemocytes (arrows) and in the fat body (asterisks). (B-E) Third instar larvae of the following genotypes srp>encGFP (control, B), serpent-gal4,tubgal80 $80^{\text {ts }}$, UAS-encGFP, UAS-gcm ${ }^{\mathrm{DN}} / \mathrm{srp}>\mathrm{gcm}$ DN, C), serpent-gal4, tub-gal80 ${ }^{\text {ts }}$, UAS-encGFP,UAS$\mathrm{gcm}^{\mathrm{N} 7-4 \mathrm{DN}}$ (srp>gcm ${ }^{\mathrm{N7}-4 \mathrm{DN}}, \mathrm{D}$ ) and dpias $1 / \mathrm{dpias}^{2}$ (E). Note that loss of function of $\mathrm{gcm}(C)$ or dpias (E) induces similar melanotic tumor phenotypes. (F) Hemocytes from at least ten different LIII larvae were examined for each genotype (control, srp>gcm ${ }^{\mathrm{DN}}$ and $\mathrm{srp}>\mathrm{gcm}^{\mathrm{N7}-4 \mathrm{DN}}$ ), and the average number of the three hemocyte subsets are presented. Bars indicate the standard deviation. Note that $\mathrm{gcm}$ loss of function induces massive differentiation of lamellocytes; ANOVA analysis shows a significant difference in lamellocyte number $(p<0.001)$ between srp $>g_{\mathrm{cm}}^{\mathrm{DN}}$ and all other genotypes. (G) Schematic representation of Drosophila development at $18^{\circ} \mathrm{C}$ and the phenotypes induced upon shifting $\mathrm{srp}>\mathrm{gcm}^{\mathrm{DN}}$ animals at restrictive temperature $\left(29^{\circ} \mathrm{C}\right)$ during different developmental stages. Note that when expression of $\mathrm{gcm}^{\mathrm{DN}}$ construct is induced in LI, large and numerous tumors are found in all LIII larvae. The penetrance decreases to $50 \%$ when $\mathrm{gcm} \mathrm{DN}^{\mathrm{DN}}$ induced in LII and the size and the number of tumors are smaller. Expression induced in LIII does not cause any melanotic tumor. Note that $\mathrm{gcm}{ }^{\mathrm{DN}}$ expression prior to the larval stages induces embryonic lethality (cross). Scales bar in (A, $\left.A^{\prime}\right) 50 \mu m$; in (B) 1 mm.

Expression of a fusion protein containing the Gcm DNA binding domain and the repressor domain of Engrailed $(\mathrm{gcm} P M$ provides a dominant negative approach that induces the same phenotypes as those induced by a deficiency eliminating both $\mathrm{gcm}$ and its homolog gcm2(Soustelle et al., 2004). The use of this transgenic construct allows to overcome the embryonic lethality induced by the $\mathrm{gcm}$ mutation. Indeed, expression of the $\mathrm{gcm} \mathrm{CN}^{D}$ construct can be controlled spatially and temporally by using the TARGET system, which is based on the expression of a temperaturesensitive mutation of the Gal80 protein $\left(\mathrm{Gal} 8 \mathrm{O}^{\text {ts }}\right)$, a repressor of Gal4 function (McGuire et al., 2003). Conditional expression of the $\mathrm{gcm}^{D N}$ construct has already been successfully used to clarify the role of $\mathrm{gcm}$ genes in the nervous system and in tendon cells (Soustelle and Giangrande, 2007b; Soustelle etal., 2004; Soustelle et al., 2007).

In a first trial, we used the serpent-ga/4 line, which expresses Gal4 in all tissues involved in the innate immune response at postembryonic stages (Fig. 2A,A'). This includes the lymph gland, the organ producing hemocytes during larval development (Lanot $e t$ al., 2001), the fat body, which is known to play a role in the humoral immune response (for reviews, see Cherry and Silverman, 2006; Leclerc and Reichhart, 2004; Lemaitre and Hoffmann, 2007), as well as hemocytes (Crozatier et al., 2004). To bypass the embryonic lethality induced by loss of $\mathrm{gcm}$, we expressed the dominant negative construct starting from larval stages (shift at the restrictive temperature, $29^{\circ} \mathrm{C}$, during the first instar larval stage or $\mathrm{LI}$ ), using the line serpent-ga/4, tub-gal $80^{\prime s}, U A S-g c m^{D N}, U A S$-encGFP $\left(s r p>g c m^{P M}\right)$. Induction of the $g c m^{D N}$ construct at these stages leads to the formation of melanotic tumors (Fig.2C). This phenotype is $100 \%$ penetrant $(n>200)$ and all animals die at the pupal stage. Importantly, mutant animals do not show such phenotype at permissive temperature $\left(18^{\circ} \mathrm{C}\right)$ and are perfectly viable and fertile, due to the fact that Gal80 is active and represses Gal4 activity. We also noticed that mutant animals display a delay in development after the LIII stage as well as a disintegration of the fat body (data not shown), as it had been previously observed in dpias mutant larvae (Betz et al., 2001; Hari et al., 2001), suggesting that $\mathrm{gcm}$ and dpias act in concert during post-embryonic hematopoiesis. Importantly, the observed delay in development occurs during the LIII/pupariation transition, after the appearance of melanotic tumors, indicating that the formation of melanotic tumors is not due to development delay. Finally, we used a mutant construct, $g \mathrm{~cm} N 7-4 D N$, which carries a mutation abolishing DNA binding (Miller et al., 1998; Soustelle et al., 2004; Vincent et al., 1996). serpent-gal4, tub-gal80ts, UAS-gcm ${ }^{N 7-4 D N}$, UAS-encGFP larvae expressing the $g c m^{N 7-4 D N}$ construct do not show any phenotype (Fig.2D), confirming the specificity of the defects observed in $s r p>g \mathrm{~cm}^{D N}$ larvae.

Previous studies have shown that the melanotic tumor phenotype is associated with extensive lamellocyte differentiation (Harrison et al., 1995; Luo et al., 1995). To demonstrate that this is also the case in animals lacking $\mathrm{Gcm}$ activity in immune tissues, we counted the number of hemocytes in third instar larvae (LIII). While control larvae (serpent-gal4,UAS-encGFPand srp $>g \mathrm{~cm} \mathrm{~N}^{N \text { - }}$ 


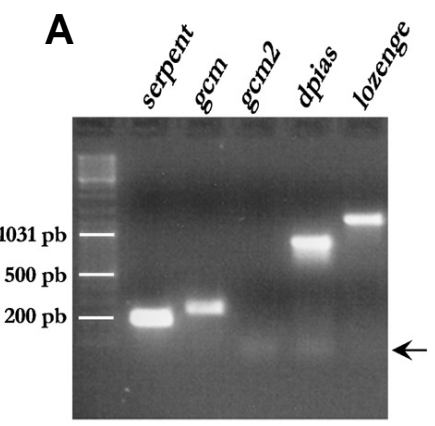

$s t p^{+}$

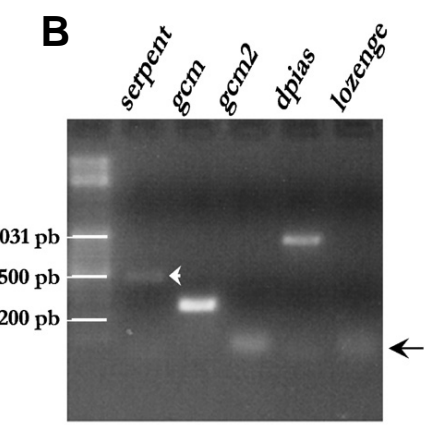

$\operatorname{stp}$
$4 D M$ do not contain any lamellocyte (Fig.2F), $s r p>g c m p N$ animals display a strong increase in lamellocyte production (Fig.2F). Moreover, the ratio of plasmatocytes as compared to total hemocyte number is significantly decreased in $s r p>g c m^{D N}$ animals $(10,5 \%$ versus $97 \%$ in srp>encGFP larvae, $p<0,001$ ), as it had been previously observed in other mutant conditions leading to the production of melanotic tumors (Betz et al., 2001; Hari et al., 2001). Interestingly, we observed that the melanotic tumor phenotype is less severe (fewer larvae showing fewer tumors) when the expression of the $\mathrm{gcm}^{D N}$ construct is induced after $\mathrm{LI}$ and no tumor was observed upon $\mathrm{gcm}^{D N}$ induction at early LIII, suggesting that $\mathrm{gcmis}$ required during early larval development for normal hematopoiesis (Fig.2G).

\section{Tissue specific requirement of $\mathrm{Gcm}$}

In order to determine the tissue-specific requirement of $\mathrm{gcm}$ during post-embryonic hematopoiesis, we assessed its expression profile. We first analyzed enhancer trap lines inserted into the regulatory regions of $\mathrm{gcm}$ ( $\mathrm{gcm}$-ga/4 and $r$ A87lines) and found no expression in serpent-positive tissues (data not shown), as had been described in previous studies (Bataille et al., 2005). Be-
Fig. 3. $\mathbf{g c m}$ is expressed in cells of the immune system. $R T-P C R$ experiments on GFP-positive or GFP-negative cells collected from serpent-gal4,UAS-encGFP larvae upon Fluorescence-activated cell sorting (FACS). Note that serpent-positive cells express serpent (expected size: 197 bp), lozenge (expected size: 1224 bp), dpias (expected size: 839 bp) and $\mathrm{gcm}$ (expected size: $245 \mathrm{bp}$ ) (A) whereas serpent-negative cells only express dpias and gcm (B). gcm2 is not detected (expected size: $351 \mathrm{bp}$ ). Black arrows in $(A, B)$ show the primers. White arrowhead in $(B)$ shows an amplification product issued from serpent genomic DNA lexpected size: 450 bp).

cause $\mathrm{gcm}$ function is required during early larval development, a stage making in situ hybridization experiments difficult, we performed RT-PCR experiments on cells separated by fluorescence activated cell sorter (FACS) (Fig.3). For this purpose, we collected serpent-gal4,UAS-GFP animals at $\mathrm{LI}$, dissociated them into single cells and collected two fractions: the serpent-positive cells expressing GFP and the serpent-negative cells, which do not express GFP. These two fractions were then used to perform RTPCR experiments by using different couples of primers (serpent, $\mathrm{gcm}, \mathrm{gcm} 2$, lozenge, dpias). This approach was validated by two sets of data: 1) serpent-positive cells express serpent, lozenge and dpias (Fig.3A), which are known to be transcribed in immune tissues, 2) serpent as well as the crystal cell-specific marker lozenge are not detected in serpent-negative cells (Fig.3B).

As shown on Fig. $3, \mathrm{gcm}$ is present in serpent-negative cells due to its expression in neural tissues (Fig.3B), but also in serpent-positive cells (Fig.3A). Interestingly, gcm2 was not detected (Fig.3), indicating that only $\mathrm{gcm}$ is expressed in tissues involved in the innate immune defense.

Because the serpent-gal 4 line drives expression in several cell types, we aimed at identifying in which cells $\mathrm{Gcm}$ acts by using lines that drive expression in restricted cell populations. First, the Gal4 expression profile was established by crossing the driver with a GFP reporter line and analyzed in L1 under a fluorescent
Fig. 4. Expression profile of gal4 lines used in this study. (A) For each gal4 driver, a cross with a UAS-GFP reporter line was performed and analyzed under a macroscope. Columns report the GFP expression profile in the immune system (lymph gland, hemocytes and fat body) and in other tissues in LI larvae. Red rows indicate drivers that induce melanotic tumors upon crosses with the UAS-gcm DN line. In the case of the collagen-gal4 line, we induced $\mathrm{gcm}^{D N}$ expression at LII as induction at $\mathrm{LI}$ triggers lethality. (B) Schematic diagram of third instar lymph gland. The lymph gland flanks the dorsal vessel (DV) and each lobe is separated by pericardial cells (PC). The anterior lobe displays three distinct zones: the cortical zone (CZ), where maturing hemocytes are present; the medullary zone (MZ), which contains prohemocytes; and the posterior signaling center (PSC), which contains a small cluster of signaling cells. Posterior lobes contain immature hemocytes. Note that in LI larvae, only anterior lobes are present (as shown in Fig. 2), posterior lobes appearing at later stages.
A

\begin{tabular}{|c|c|c|c|c|c|c|}
\hline \multirow{2}{*}{$\underbrace{\begin{array}{r}\text { Expression } \\
\text { domain }\end{array}}_{\text {Driver }}$} & \multirow{2}{*}{ Lymph gland } & \multicolumn{3}{|c|}{ Hemocytes } & \multirow{2}{*}{ Fat body } & \multirow{2}{*}{ Other tissues } \\
\hline & & Prohemocytes & Crystal cells & Plasmatocytes & & \\
\hline serpent & CZ, MZ, PSC & + & + & + & + & - \\
\hline $\mathrm{gcm}$ & - & - & - & - & - & $\begin{array}{l}\text { Nervous system, } \\
\text { peritracheal cells }\end{array}$ \\
\hline peroxydasin & CZ & + & - & + & - & - \\
\hline lozenge & CZ & + & + & - & - & - \\
\hline collagen & - & + & + & + & + & - \\
\hline serrate & PSC & - & - & - & - & $\begin{array}{c}\text { Nervous system, } \\
\text { peritracheal cells, gut }\end{array}$ \\
\hline hemolectin & - & + & - & + & - & - \\
\hline domeless & MZ & - & - & - & - & $\begin{array}{l}\text { Salivary glands, gut, } \\
\text { trachea }\end{array}$ \\
\hline hemese & $\begin{array}{c}\text { CZ, MZ, PSC } \\
\text { (weak) }\end{array}$ & + & + & + & - & Salivary glands, gut \\
\hline pumpless & - & - & - & - & + & - \\
\hline
\end{tabular}

B

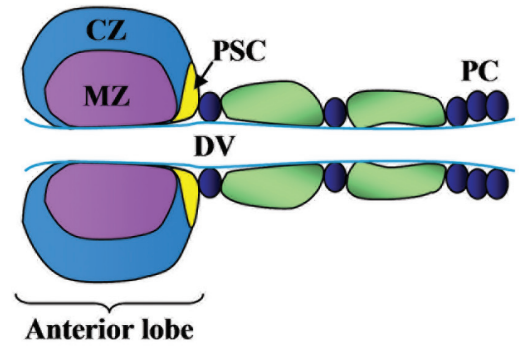


A

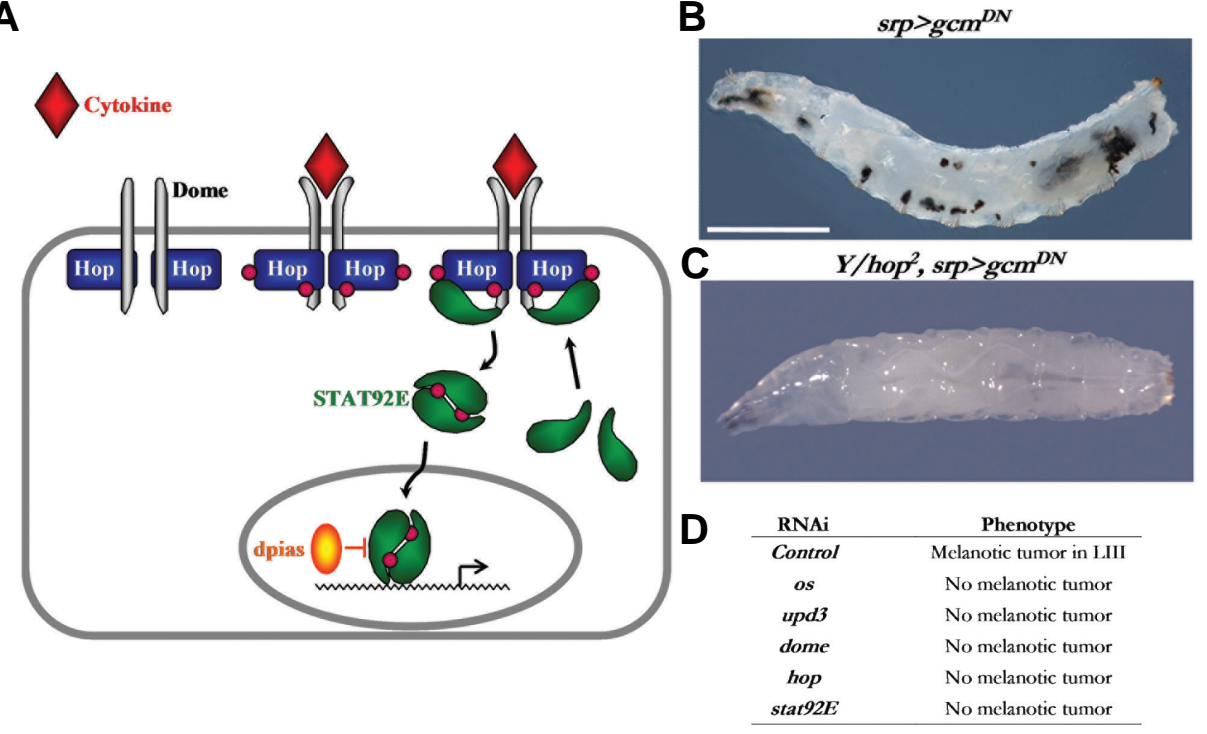

Fig. 5. The melanotic tumor phenotype induced by $\mathrm{gcm}$ loss of function requires the JAK/STAT pathway. (A) Schematic representation of the JAK/STAT pathway. Following binding of a cytokine (Os or Upd) to its cognate receptor Dome, receptor-associated Hop is activated. STAT92E proteins dimerize upon tyrosine phosphorylation by the Hop kinase and subsequently translocate into the nucleus, where they modulate expression of target genes. dpias interacts with activated STAT92E dimers and inhibits their DNA binding or their transactivating capacity.(B,C) $Y /+$, serpentgal4, tub-gal80ts, UAS-encGFP, UAS-gcm DN larva displays melanotic tumors (C) whereas $\mathrm{Y} /$ hop ${ }^{2}$, serpent-gal4, tub-gal80ts, UASencGFP,UAS-gcm DN larva does not (C). (D) To analyze the effects of JAK/STAT pathway downregulation, we crossed the serpent-gal4, tubgal80"s, UAS-encGFP,UAS-gcm DN line with a UAS-RNAi transgenic construct for each member of the JAK/STAT pathway los, Upd3, dome, hop, stat92E). While the control line induces melanotic tumors with $100 \%$ penetrance (serpent-gal4, tub-gal80ts, UAS-encGFP, UAS-gcm ${ }^{\text {DN }}$ ), tumors are absent in serpent-gal4, tub-gal80 ${ }^{\text {ts }}$, UASencGFP,UAS-gcm DN larvae also carrying an RNAi transgenic construct for one member of the JAK/STAT pathway. Note that for each RNAi construct, we analyzed between forty and sixty larvae and never found any tumor, indicating a $100 \%$ penetrance of the tumor suppression phenotype.

macroscope. We crossed UAS-gcm ${ }^{D N}$ with peroxydasin-gal4, lozenge-gal4, serrate-gal4, hemolectin-gal4, domeless-gal4and hemese-ga/4 drivers, which express Gal4 in specific territories of the immune system (lymph gland, prohemocytes, circulating hemocytes, see Fig.4B). By using these lines, we did not observe any melanotic tumor phenotype (Fig.4A), excluding a role of $\mathrm{Gcm}$ in these cell types. In contrast, expression of $\mathrm{gcm} \mathrm{cm}^{D N}$ in the fat body by using the collagen-gal4 line, induces the formation of melanotic tumors (Fig.4A), similar to the phenotype induced by the serpent-ga/4 line. We confirmed this phenotype by expressing $\mathrm{gcm}^{D N}$ specifically in the larval fat body by using the ppl-gal4 line (data not shown), a fat body specific driver (Colombani et al., 2005).

Altogether, these data strongly suggest that $\mathrm{gcm}$ is required in the fat body during early larval life and that its misregulation leads to lamellocyte production and melanotic tumor formation.

\section{Gcm genetically interacts with JAK/STAT signaling path- way}

dpias was identified as a cofactor for $\mathrm{Gcm}$ and melanotic tumors were observed in mutant conditions for both genes. In Drosophila, dpiasis known to play a role in the modulation of the JAK/STAT signal transduction pathway (Betz et al., 2001). This pathway is activated by the binding of an extracellular ligand (Unpaired (Upd) or Outstretched (Os) cytokines) to its receptor (Domeless (Dome)) (Fig.5A) (Arbouzova and Zeidler, 2006). This induces the intracellular recruitment and the phosphorylation of Hopscotch (Hop), the only kinase that is described as being involved in the JAK/STAT pathway in flies (Binari and Perrimon, 1994; Perrimon and Mahowald, 1986). Subsequently, the phosphorylated Hop kinase acts onto cytoplasmic STAT, which translocates to the nucleus and activates its target genes. The role of dpias is to bind to STAT and inhibit its function. Interestingly, mutants for several components that activate the JAK/STAT pathway display a melanotic tumor phenotype associated with massive lamellocyte differentiation (Betz et al., 2001; Hari et al., 2001; Harrison et al., 1995; Luo et al., 1995). Moreover, the tumor phenotype induced by the hop ${ }^{\text {Tum-1 }}$ allele, which codes for a constitutively active kinase (Harrison et al., 1995; Luo et al., 1995), is rescued by ectopic expression of dpias (Betz et al., 2001).

To determine whether the JAK/STAT pathway is required for lamellocyte production and melanotic tumor formation induced by loss of $\mathrm{gcm}$, we performed an epistatic analysis by using the $h o p^{2}$ null mutation. Contrary to what was observed in $s r p>g c m^{D N}$ larvae (Fig. $5 \mathrm{~A}$ ), none of the $h o p^{2} / Y, s r p>g c m^{D N}$ larvae shows melanotic tumors or lamellocyte production (Fig.5B). Importantly, the two other phenotypes observed in $s r p>g \mathrm{~cm}^{D N}$ larvae (fat body disintegration and developmental delay after the LIII stage) are also completely suppressed by the hop mutation. Altogether, these data show that $\mathrm{gcm}$ acts upstream of hop to control post-embryonic hematopoiesis.

To further confirm that the JAK/STAT pathway is required for melanotic tumor formation induced by loss of $\mathrm{Gcm}$, we knocked down five members (upd3, os, dome, hop, stat92E) of the JAK/ STAT pathway by using transgenic lines carrying RNAi constructs. The down-regulation of each of these genes in $s r p>g c m^{D N}$ animals (shift at $29^{\circ} \mathrm{C}$ starting from LI, as above) completely suppresses the melanotic tumor phenotype (Fig.5D), clearly showing that the JAK/STAT pathway acts downstream of $\mathrm{gcm}$. Finally, the delay in development as well as the fat body disintegration observed in $s r p>g c m^{D N}$ larvae are also rescued by the down-regulation of these members of the JAK/STAT pathway.

We identified several potential partners of $\mathrm{Gcm}$, one of them being dpias, a gene required in post-embryonic hematopoiesis.

Blocking $\mathrm{Gcm}$ function in the fat body triggers a melanotic tumor phenotype, similar to what is observed in dpias mutant larvae.

Members of the JAK/STAT signaling cascade, which are 
known for their role in post-embryonic hematopoiesis and rely on dpias, act downstream of $\mathrm{gcm}$.

\section{Discussion}

During nervous system development of Drosophila embryos, gcmacts as a glial determinant, being necessary and sufficient to induce the glial fate (Akiyama-Oda et al., 1998; Bernardoni et al., 1998; Hosoya etal., 1995; Jones etal., 1995; Vincent etal., 1996), for review (Soustelle and Giangrande, 2007a). Interestingly, gcm also acts as a cell fate determinant in hematopoietic lineages, where it controls the plasmatocyte/crystal cell fate choice (Alfonso and Jones, 2002; Bataille et al., 2005; Bernardoni et al., 1997). Despite the fact that $\mathrm{gcm}$ also has a gliogenic role at postembryonic stages (Chotard et al., 2005; Soustelle and Giangrande, 2007b; Soustelle et al., 2007; Yoshida et al., 2005), its function in larval hematopoiesis has not been elucidated. We here identify dpias as a cofactor of $\mathrm{Gcm}$ and show that loss of function for each of these genes triggers the same larval phenotype. In addition, we demonstrate that $\mathrm{Gcm}$ acts in the fat body and upstream of the JAK/STAT pathway to maintain blood cell homeostasis at postembryonic stages. Thus, Gcm activity is able to trigger different pathways and depends on protein-protein interactions.

The identification of putative cofactors constitutes a starting point to better understand Gcm mode of action. Future challenge will be to identify which target genes are specifically activated by Gcm-dpias complex in the fat body and how this molecular cascade acts on JAK/STAT signaling to maintain blood cell homeostasis. Whether dpias also acts in concert with $\mathrm{Gcm}$ during nervous system development will also be the purpose of future analyses.

Our study identifies the fat body as a tissue that controls blood homeostasis. Until now, the hematopoietic role of the fat body has been associated to the humoral but not to the cellular response. During bacterial infection, circulating hemocytes signal the presence of pathogens to the fat body, which in turn produces antimicrobial peptides (for reviews, see Cherry and Silverman, 2006; Leclerc and Reichhart, 2004; Lemaitre and Hoffmann, 2007). Our study identifies a role in the cellular response as the production of lamellocytes is induced by blocking $\mathrm{Gcm}$ activity in the fat body. These data therefore indicate that the fat body is necessary to maintain cellular blood homeostasis. Recent studies have shown that the fat body also plays a crucial role during development by controlling larval growth rates and the final size of adult flies. For example, a Target of Rapamycin (TOR)-mediated nutrient sensor present in the fat body detects nutrient availability and regulates insulin signaling in peripheral tissues (Mirth and Riddiford, 2007). Altogether, these data indicate that the fat body, which is considered as the 'Drosophila liver', acts as an integrator center for different processes relying on distinct signaling cascades.

Microarray studies have shown that glia- and hemocyte-specific Gcm pathways share common target genes (Altenhein et al., 2006; Freeman etal., 2003). One such example is provided by the transmembrane protein Draper, which is expressed in embryonic glia and in plasmatocytes. Interestingly, glial expression of this macrophage receptor mediates engulfment of apoptotic neurons and degenerating axons (Awasaki et al., 2006; Freeman et al., 2003; MacDonald et al., 2006). These observations call for an ancestral, scavenger role, of glia and indicate that these cells could be considered as the neural equivalent of hemocyte populations present outside the nervous system. Furthermore, these two cell populations share other properties such as their capacity to proliferate and migrate (Holz et al., 2003; Soustelle and Giangrande, 2007b). In the future, the characterization of $\mathrm{Gcm}$ target genes will help to understand the molecular mechanisms as well as the signaling pathways involved in these common features between glia and hemocytes.

The scavenger activity displayed by Drosophila glia and hemocytes also represents a primary feature of microglia, the immune cells of mammalian Central Nervous System (CNS) (Hanisch and Kettenmann, 2007). Our data open new questions on the cellular and molecular pathways involved in non self recognition. They also prompt us to speculate about the evolutionary origin of microglia and the possible role of $\mathrm{gcm}$ genes orthologs in this cell type. Indeed, despite the observation that murine gcmgenes are transcribed in the nervous system (Iwasaki et al., 2003; Kim et al., 1998), it is still unknown in which cell type are they expressed. Considering our data, we propose that $\mathrm{gcm}$ orthologs may play a role in the microglia in normal or pathological conditions and call for revisiting their role in mammalian nervous system.

\section{Materials and Methods}

\section{Yeast two-hybrid assay}

The yeast strain L40 (MATa trp1 leu2 his3L YS2::/exA-HIS3URA3::/exAlacZ) (Vojtek et al., 1993), which includes the reporter genes HIS3 and lacZ, was used. Transcription of HIS3 gene can be measured by the ability of the strain to grow in the absence of histidine, which requires the HIS3gene product. The other reporter gene, lacZ, provides a secondary assay of activation by the bait and activation-tagged proteins interacting with it, as well as quantitative information about the interaction. All transformations were performed by using the lithium acetate method (Gietz et al., 1995). Sequence encoding the DNA binding domain (DBD), the nuclear localization signal (NLS) and the protein instability element (PEST) $\left(\mathrm{Val}^{2}-\mathrm{Thr}^{263}\right.$ ) of $\mathrm{Gcm}$ were PCR amplified using the following forward and reverse oligonucleotide primers:

5'-GAATTCGTTTTGAACGGCATGCCTAT-3' and

5'- CTCGAGGGTGCTATGTGTGGGCGTCG-3'. The PCR product (Gcm ${ }^{1-}$ ${ }^{261}$ ) was subcloned in PGEM $^{\circledR}-\mathrm{T}$ and digested with EcoRI and Xhol and then inserted in frame with the LexA DBD (LexA $\left.{ }^{D B D} \mathrm{Gcm}^{1-261}\right)$ into pBTM116. The resulting fusion protein was used as bait to screen a Drosophila embryonic cDNA library (4-18h) made into pASV4 carrying the VP16 activation domain (VP16 ${ }^{\mathrm{AD}}$ ) (Beckstead et al., 2001). Yeast two-hybrid screening followed the method of Le Douarin et al. (Le Douarin et al., 2001). $\beta$-Galactosidase assays on transformants of the $L 40$ yeast strain were carried out as in (Seipel et al., 1992). To identify the Gcm domains required for interaction, we made two constructs: $\operatorname{LexA}^{\mathrm{DBD}} \mathrm{Gcm}^{1-233}$ and LexA ${ }^{D B D} G \mathrm{~cm}^{1-186}$, which lack the PEST or the PEST and NLS domains, respectively, using the following reverse oligonucleotide primers:

5'- CTCGAGACCCATCCTTCTGCGCTTGC-3' and

5'- CTCGAGCAAAAGTCGCCTGGCTTCCG-3'.

\section{Plasmid constructions}

Two Flag epitope tag (DYKDDDDK) were fused to the C-terminus of Gcm by overlapping PCR using the following forward and reverse oligonucleotide primers:

5'-TTGCAATGGTCGCTTGGAAATCCAGGCTT-3' and

5'-CCGCGGTCATTTATCGTCATCGTCTTTGTAGTCTTTATCGT CATCGTCTTTGTAGTCGCAATAGATGGGATCCGTGCTGTTGAC-3'. 
The wild-type C-terminus of $\mathrm{gcm}$ was removed from pUASt- $\mathrm{gcm}$ upon Sacll digestion and the Flag-tagged PCR product digested by Sacll was inserted. HA epitope tag (YPYDVPDYA) was fused to the C-terminus of dpias $^{537}$ isoform (gift from A. Betz) by overlapping PCR using the following forward and reverse oligonucleotide primers:

5'-GCGGCCGCATGGTGCAGATGCTTCGAGT-3' and 5'-GGTACCTCATGCGTAATCTGGAACATCGTATGGGTAAGGACTATC TAGAAGATCAATTACGGAAT-3'. The PCR product was digested by Notl and Kpnl and cloned into pUASt.

DNA transfections, immunoprecipitations and Western Blot assay Drosophila S2 cells were cultured in Schneider cell medium (Gibco $\mathrm{BRL} /$ Invitrogen) $+10 \%$ fetal calf serum. Transient transfection was performed using effectene (Qiagen), according to the manufacturer's instructions, using $2 \mu \mathrm{g}$ of DNA containing the following: $500 \mathrm{ng}$ of reporter DNA (pUASt-encGFP), 500 ng of pMET-Gal4 (expresses Gal4 under control of the copper-inducible metallothionine promoter) and $500 \mathrm{ng}$ of each expression vector (pUASt-gcm ${ }^{\mathrm{FLAG}}$ and pUASt-dpias ${ }^{\mathrm{HA}}$ ). Transgenes expression was induced $24 \mathrm{~h}$ later by adding copper sulfate at 1 $\mathrm{mM}$. Cells were harvested 48 hours after transfection in cold PBS, pelleted, washed, and resuspended in lysis buffer $(400 \mathrm{mM} \mathrm{KCl}, 20 \mathrm{mM}$ Tris- $\mathrm{HCl}$ (pH 7.5), 20\% glycerol, $5 \mathrm{mM}$ DTT, $0.4 \mathrm{mM}$ PMSF). After three cycles of freeze-thaw in liquid nitrogen, the resulting cell lysate was diluted four times with the lysis buffer without $\mathrm{KCl}$ to give a final concentration of $100 \mathrm{mM} \mathrm{KCl}$ and then cleared by centrifugation for $5 \mathrm{~min}$ at $13000 \mathrm{rpm}$. The protein concentration was determined by the Bradford assay. Three hundred micrograms of protein extract, adjusted to $1 \mathrm{ml}$ with RIPA buffer (PBS, $0.1 \%$ SDS, $0.5 \%$ sodium deoxycholate, $0.5 \%$ NP-40), were incubated for 2 hours at $4^{\circ} \mathrm{C}$ with $30 \mu \mathrm{l}$ of anti-Flag M2 Affinity Gel (Sigma A-1205). The agarose beads were then recovered by centrifugation and washed three times with $1 \mathrm{ml}$ of RIPA buffer. The adsorbed proteins were dissociated by boiling for $5 \mathrm{~min}$ in $30 \mu \mathrm{l}$ of Laemmli buffer, resolved by SDS-polyacrylamide gel electrophoresis and electrotransferred onto a nitrocellulose filter. Blocking, washing, and incubation of the membrane with antibodies were carried out in PBS containing 5\% skimmed dry milk and $0.1 \%$ Triton X-100. Mouse anti-Flag M2 antibody (Sigma F3165, 1/5000) and mouse anti-HA antibody (1/2000) were used to detect the Flag-tagged $\mathrm{Gcm}$ and the the HA-tagged dpias, respectively. After washing (PBS, $0.1 \%$ Triton X-100) and blocking (PBS, $5 \%$ skimmed dry milk, $0.1 \%$ Triton X-100), blots were further incubated with horseradish peroxidase-linked rabbit anti-mouse immunoglobulins (Jackson Immunoresearch, 1/5000).

\section{Hemocyte counting}

Larvae were staged according to procedures described in (Andres and Thummel, 1994). Staged larvae were first washed in PBS, bled onto glass slides and labeled with anti-GFP, anti-peroxidasin (Nelson et al., 1994) and DAPI according to the procedure described in (Asha et al., 2003). Circulating hemocytes were manually counted and classified as either plasmatocytes or lamellocytes, based on their morphology and expression of plasmatocyte marker peroxidasin (data not shown). Circulating crystal cells were not counted separately. Instead, we counted sessile crystal cells in the last two posterior dorsal segments of third-instar larvae (Duvic et al., 2002). They were visualized by heating the larvae for $10 \mathrm{~min}$ at $60^{\circ} \mathrm{C}$ in a water bath. Total circulating hemocytes as well as crystal cells were counted from at least ten larvae of each genotype.

Data were compared using one-way analysis of variance (ANOVA) followed by Dunnett's post hoc test to determine statistical differences after multiple comparisons (SPSS, SPSS Inc., Chicago, IL). A probability (p) value of less than 0.05 was considered significant.

\section{Fly strains and transgenic lines}

Wild-type strain was Sevelen. $\mathrm{gcm}^{26}$ mutant described in (Kammerer and Giangrande, 2001; Vincent et al., 1996) carries a small deletion in the regulatory region of $\mathrm{gcm}$. dpias ${ }^{1}$ mutant carries a leucine to methionine change at aminoacid 327 (Hari et al., 2001). Recombinant between $\mathrm{gcm}^{26}$ and $d p i a s^{1}$ was created and used for genetic experiments. Flies were raised at $25^{\circ} \mathrm{C}$ on standard medium, except for experiments done with tub-gal $80^{t s}$ transgene (Bloomington stock center) and genetic experiments shown in table 1 (see below). Transgenic line carrying serpent-gal4 (srp-gal4) construct was obtained from M. Meister (Crozatier et al., 2004). ppl-gal4 was obtained from P. Leopold (Colombani et al., 2005). UAS$\mathrm{gcm}^{D N}$ was used to block $\mathrm{gcm}$ function and $U A S-g \mathrm{~cm}^{N 7-4 D N}$ as a control (Soustelle et al., 2004). UAS-mCD8GFP targets GFP to the membrane (Bloomington stock center). UAS-encGFP targets GFP to nucleus and cytoplasm (gift of C. Desplan). A serpent-gal4,tub-gal80ts, UASencGFP, UAS-gcm ${ }^{N}$ line was established and maintained at $18^{\circ} \mathrm{C}$. UASRNAistocks (os, upd3, dome, hop and stat92E) were obtained from the Vienna Drosophila RNAi Center (VDRC). serrate, hemolectin, domelessgal4 (all gifts from U. Banerjee), lozenge, hemese and collagen-gal4 (all three from the Bloomington stock center) were used for targeted expression of the $\mathrm{Gcm}^{D N}$ construct. $r A 87$ and $\mathrm{gcm}$-ga/4enhancer trap lines carry a P-element inserted into the gcm promoter (Jones et al., 1995; Vincent et al., 1996). hop $p^{2}$ mutant was obtained from Bloomington Stock center. Larvae were analyzed using the Leica Macro-Fluo ${ }^{\mathrm{TM}}$.

\section{Preparation and separation of larval cells}

First instar larvae of the serpent-Gal4, UAS-encGFP genotype were dissociated in S2 medium (Schneider's insect medium (Gibco BRL) supplemented with $10 \%$ fetal calf serum and 3 mM EDTA) using a homogenizer by gentle movements. Cells were washed two times in S2 medium, pelleted at $1000 \mathrm{rpm}$ for $10 \mathrm{~min}$ at $4^{\circ} \mathrm{C}$, resuspended in $3 \mathrm{ml}$ of $\mathrm{S} 2$ medium and stored on ice. Cells were separated using fluorescenceactivated cell sorting (FACS; FACSDiVa, Becton Dickinson) and populations analyzed for GFP expression by flow cytometry to verify sample purity. Samples showing purity lower than $90 \%$ were discarded.

\section{RT-PCR experiments}

RNA from $10^{6}$ separated cells was prepared using Trizol reagent (Gibco BRL) according to the manufacturer's instructions. The RNA pellet was dried and dissolved in RNA-free water, then quantified by NanoDrop ${ }^{\circledR}$ ND-1000 spectrophotometer. Reverse transcription reactions were performed using the Protoscript First Strand cDNA Synthesis kit (New England Biolabs) using $1 \mu \mathrm{g}$ total RNA in a $50 \mu \mathrm{l}$ reaction volume with random primers. To avoid false positive results due to amplification of contaminating genomic DNA in the cDNA preparation, we used primers spanning exon-exon junctions. Primers for polymerase chain reaction (PCR) were as follows:

gcm 5'-GAAGCAGCAGGGCAAACAGT-3' (forward) and

5'- ATTCCCTGGCCAACATTACG-3' (reverse);

gcm2 5'-TCGCCAAGAAGTCGGTCATT-3' (forward) and 5'-TTGCATGGTAGATGGGATAG-3' (reverse);

dpias 5'-ACATTCGCAACAGCTCCAAG-3' (forward) and 5'-GTCCTGTGCTGGGGACAAAT-3' (reverse);

lozenge 5'-TGCCAGGTCTACAAGCCGAA-3' (forward) and 5'-CTGAGCTCTTGAAGTTAGGG-3' (reverse); serpent 5'-AATGCATGCGGCCTGTACTA-3' (forward) and 5'-AGGACGACACCAACGTTATG-3' (reverse). PCR conditions were as follows: denaturation at $95^{\circ} \mathrm{C}$ for $45 \mathrm{sec}$, annealing at $65^{\circ} \mathrm{C}$ for 1 min, polymerization at $72^{\circ} \mathrm{C}$ for $1 \mathrm{~min}$ ( 35 cycles), and terminal extension at $72^{\circ} \mathrm{C}$ for $10 \mathrm{~min}$.

\section{Acknowledgements}

We thank the Bloomington and Vienna Drosophila Stock centers, $M$. Meister, C. Desplan, U. Banerjee and P. Leopold for flies. We thank M. Boeglin, D. Hentsch and J.L. Vonesch for assistance with imaging. Confocal microscopy facility was financed by MESR (95. V.0015). Thanks to all group members for helpful advices, N. Arbogast and C. Delaporte for keeping fly stocks. This work was supported by Institut National de la Santé et de la Recherche Médicale, Centre National de la Recherche 
Scientifique, Hôpital Universitaire de Strasbourg, Association pour la Recherche contre le Cancer, Ligue contre le cancer, Agence Nationale de la Recherche and EEC (GRANT QLG3-CT-2000-01224). C. Jacques was supported by MRT and ARC fellowships, L. Soustelle was supported by ARC and AFM fellowships, I. Nagy was supported by CNRS and FRM fellowships.

\section{References}

AKIYAMA, Y., HOSOYA, T., POOLE, A. M. and HOTTA, Y. (1996). The gem-motif: a novel DNA-binding motif conserved in Drosophila and mammals. Proc. Natl. Acad. Sci. USA 93, 14912-14916.

AKIYAMA-ODA, Y., HOSOYA, T. and HOTTA, Y. (1998). Alteration of cell fate by ectopic expression of Drosophila glial cells missing in non-neural cells. Development Genes and Evolution 208, 578-585.

AKIYAMA-ODA, Y., HOSOYA, T. and HOTTA, Y. (1999). Asymmetric cell division of thoracic neuroblast 6-4 to bifurcate glial and neuronal lineage in Drosophila. Development 126, 1967-1974.

ALFONSO, T. B. and JONES, B. W. (2002). gcm2 promotes glial cell differentiation and is required with glial cells missing for macrophage development in Drosophila. Dev. Biol. 248, 369-383.

ALTENHEIN, B., BECKER, A., BUSOLD, C., BECKMANN, B., HOHEISEL, J. D. and TECHNAU, G. M. (2006). Expression profiling of glial genes during Drosophila embryogenesis. Dev. Biol. 296, 545-560

ANDRES, A. J. and THUMMEL, C. S. (1994). Methods for quantitative analysis of transcription in larvae and prepupae. Methods in Cell Biology 44, 565-573.

ARBOUZOVA, N. I. and ZEIDLER, M. P. (2006). JAK/STAT signalling in Drosophila: insights into conserved regulatory and cellular functions. Development 133, 2605-2616.

ASHA, H., NAGY, I., KOVACS, G., STETSON, D., ANDO, I. and DEAROLF, C. R. (2003). Analysis of Ras-induced overproliferation in Drosophila hemocytes. Genetics 163, 203-215.

AWASAKI, T., TATSUMI, R., TAKAHASHI, K., ARAI, K., NAKANISHI, Y., UEDA, R. and ITO, K. (2006). Essential role of the apoptotic cell engulfment genes draper and ced- 6 in programmed axon pruning during Drosophila metamorphosis. Neuron 50, 855-867.

BATAILLE, L., AUGE, B., FERJOUX, G., HAENLIN, M. and WALTZER, L. (2005). Resolving embryonic blood cell fate choice in Drosophila: interplay of GCM and RUNX factors. Development 132, 4635-4644.

BECKSTEAD, R., ORTIZ, J. A., SANCHEZ, C., PROKOPENKO, S. N., CHAMBON, P., LOSSON, R. and BELLEN, H. J. (2001). Bonus, a Drosophila homolog of TIF1 proteins, interacts with nuclear receptors and can inhibit betaFTZ-F1dependent transcription. Molecular Cel/7, 753-765.

BERNARDONI, R., KAMMERER, M., VONESCH, J. L. and GIANGRANDE, A (1999). Gliogenesis depends on glide/gcm through asymmetric division of neuroglioblasts. Dev. Biol. 216, 265-275.

BERNARDONI, R., MILLER, A. A. and GIANGRANDE, A. (1998). Glial differentiation does not require a neural ground state. Development 125, 3189-3200.

BERNARDONI, R., VIVANCOS, V. and GIANGRANDE, A. (1997). glide/gcm is expressed and required in the scavenger cell lineage. Dev. Biol. 191, 118-130.

BETZ, A., LAMPEN, N., MARTINEK, S., YOUNG, M. W. and DARNELL, J. E., JR. (2001). A Drosophila PIAS homologue negatively regulates stat92E. Proc. Natl. Acad. SCi. USA 98, 9563-9568.

BEUCHLE, D., SCHWARZ, H., LANGEGGER, M., KOCH, I. and ABERLE, H. (2007). Drosophila MICAL regulates myofilament organization and synaptic structure. Mech. Dev. 124, 390-406.

BINARI, R. and PERRIMON, N. (1994). Stripe-specific regulation of pair-rule genes by hopscotch, a putative Jak family tyrosine kinase in Drosophila. Genes \& Development 8, 300-312.

BROWN, J. L., FRITSCH, C., MUELLER, J. and KASSIS, J. A. (2003). The Drosophila pho-like gene encodes a YY1-related DNA binding protein that is redundant with pleiohomeotic in homeotic gene silencing. Development 130 , 285-294.

CHERRY, S. and SILVERMAN, N. (2006). Host-pathogen interactions in drosophila: new tricks from an old friend. Nature Immunol. 7, 911-917.
CHOTARD, C., LEUNG, W. and SALECKER, I. (2005). glial cells missing and gcm2 cell autonomously regulate both glial and neuronal development in the visual system of Drosophila. Neuron 48, 237-251.

CHOU, C. C., CHANG, C., LIU, J. H., CHEN, L. F., HSIAO, C. D. and CHEN, H. (2007). Small ubiquitin-like modifier modification regulates the DNA binding activity of glial cell missing Drosophila homolog a. J. Biol. Chem. 282, 2723927249.

COLOMBANI, J., BIANCHINI, L., LAYALLE, S., PONDEVILLE, E., DAUPHINVILLEMANT, C., ANTONIEWSKI, C., CARRE, C., NOSELLI, S. and LEOPOLD, P. (2005). Antagonistic actions of ecdysone and insulins determine final size in Drosophila. Science 310, 667-670.

CROZATIER, M., UBEDA, J. M., VINCENT, A. and MEISTER, M. (2004). Cellular immune response to parasitization in Drosophila requires the EBF orthologue collier. PLOS Biology2, E196.

DE IACO, R., SOUSTELLE, L., KAMMERER, M., SORRENTINO, S., JACQUES, C. and GIANGRANDE, A. (2006). Huckebein-mediated autoregulation of Glide/ Gcm triggers glia specification. EMBO J25, 244-254.

DONAGHUE, C., BATES, H. and COTTERILL, S. (2001). Identification and characterisation of the Drosophila homologue of the yeast Uba2 gene. Biochem et Biophys. Acta 1518, 210-214

DUVIC, B., HOFFMANN, J. A., MEISTER, M. and ROYET, J. (2002). Notch signaling controls lineage specification during Drosophila larval hematopoiesis. Curr. Biol. 12, 1923-1927.

ESCUDERO, L. M., CAMINERO, E., SCHULZE, K. L., BELLEN, H. J. and MODOLELL, J. (2005). Charlatan, a Zn-finger transcription factor, establishes a novel level of regulation of the proneural achaete/scute genes of Drosophila. Development 132, 1211-1222.

FREEMAN, M. R., DELROW, J., KIM, J., JOHNSON, E. and DOE, C. Q. (2003) Unwrapping glial biology: $\mathrm{Gcm}$ target genes regulating glial development diversification, and function. Neuron 38, 567-580.

GIETZ, R. D., SCHIESTL, R. H., WILLEMS, A. R. and WOODS, R. A. (1995) Studies on the transformation of intact yeast cells by the LiAc/SS-DNA/PEG procedure. Yeast 11, 355-360.

GOLDFARB, D. S., CORBETT, A. H., MASON, D. A., HARREMAN, M. T. and ADAM, S. A. (2004). Importin alpha: a multipurpose nuclear-transport receptor. Trends Cell Biol. 14, 505-514.

HANISCH, U. K. and KETTENMANN, H. (2007). Microglia: active sensor and versatile effector cells in the normal and pathologic brain. Nature Neurosci. 10 , 1387-1394.

HARI, K. L., COOK, K. R. and KARPEN, G. H. (2001). The Drosophila Su(var)2-10 locus regulates chromosome structure and function and encodes a member of the PIAS protein family. Genes \& Dev. 15, 1334-1348.

HARRISON, D. A., BINARI, R., NAHREINI, T. S., GILMAN, M. and PERRIMON, N. (1995). Activation of a Drosophila Janus kinase (JAK) causes hematopoietic neoplasia and developmental defects. EMBO J. 14, 2857-2865.

HIPFNER, D. R. and COHEN, S. M. (2003). The Drosophila sterile-20 kinase slik controls cell proliferation and apoptosis during imaginal disc development. PLOS Biology 1, E35.

HIPFNER, D. R., KELLER, N. and COHEN, S. M. (2004). Slik Sterile-20 kinase regulates Moesin activity to promote epithelial integrity during tissue growth Genes \& Dev. 18, 2243-2248.

HOLZ, A., BOSSINGER, B., STRASSER, T., JANNING, W. and KLAPPER, R. (2003). The two origins of hemocytes in Drosophila. Development 130, 49554962.

HOSOYA, T., TAKIZAWA, K., NITTA, K. and HOTTA, Y. (1995). glial cells missing: a binary switch between neuronal and glial determination in Drosophila. Ce//82 1025-1036.

IWASAKI, Y., HOSOYA, T., TAKEBAYASHI, H., OGAWA, Y., HOTTA, Y. and IKENAKA, K. (2003). The potential to induce glial differentiation is conserved between Drosophila and mammalian glial cells missing genes. Development 130, 6027-6035.

JONES, B. W. (2005). Transcriptional control of glial cell development in Drosophila. Dev. Biol. 278, 265-273.

JONES, B. W., FETTER, R. D., TEAR, G. and GOODMAN, C. S. (1995). glial cells missing: a genetic switch that controls glial versus neuronal fate. Cel/82, 10131023. 
KAMMERER, M. and GIANGRANDE, A. (2001). Glide2, a second glial promoting factor in Drosophila melanogaster. EMBO J. 20, 4664-4673.

KIM, J., JONES, B. W., ZOCK, C., CHEN, Z., WANG, H., GOODMAN, C. S. and ANDERSON, D. J. (1998). Isolation and characterization of mammalian homologs of the Drosophila gene glial cells missing. Proc. Natl. Acad. Sci. USA95, 12364-12369.

LANOT, R., ZACHARY, D., HOLDER, F. and MEISTER, M. (2001). Postembryonic hematopoiesis in Drosophila. Dev. Biol. 230, 243-257.

LE DOUARIN, B., HEERY, D. M., GAUDON, C., VOM BAUR, E. and LOSSON, R. (2001). Yeast two-hybrid screening for proteins that interact with nuclear hormone receptors. Methods Molec. Biol. 176, 227-248.

LEBESTKY, T., CHANG, T., HARTENSTEIN, V. and BANERJEE, U. (2000). Specification of Drosophila hematopoietic lineage by conserved transcription factors. Science 288, 146-149.

LECLERC, V. and REICHHART, J. M. (2004). The immune response of Drosophila melanogaster. Immunological Reviews 198, 59-71.

LEMAITRE, B. and HOFFMANN, J. (2007). The host defense of Drosophila melanogaster. Annu. Rev. Immunol. 25, 697-743.

LUO, H., HANRATTY, W. P. and DEAROLF, C. R. (1995). An amino acid substitution in the Drosophila hopTum-I Jak kinase causes leukemia-like hematopoietic defects. EMBO J. 14, 1412-1420.

MACDONALD, J. M., BEACH, M. G., PORPIGLIA, E., SHEEHAN, A. E., WATTS, R. J. and FREEMAN, M. R. (2006). The Drosophila cell corpse engulfment receptor Draper mediates glial clearance of severed axons. Neuron 50, 869881.

MCGUIRE, S. E., LE, P. T., OSBORN, A. J., MATSUMOTO, K. and DAVIS, R. L. (2003). Spatiotemporal rescue of memory dysfunction in Drosophila. Science 302, 1765-1768.

MEISTER, M. and LAGUEUX, M. (2003). Drosophila blood cells. Cellular Microbiology 5, 573-580.

MILLER, A. A., BERNARDONI, R. and GIANGRANDE, A. (1998). Positive autoregulation of the glial promoting factor glide/gcm. EMBO J. 17, 6316-6326.

MIRTH, C. K. and RIDDIFORD, L. M. (2007). Size assessment and growth control: how adult size is determined in insects. Bioessays 29, 344-355.

MOHR, S. E. and BOSWELL, R. E. (1999). Zimp encodes a homologue of mouse Miz1 and PIAS3 and is an essential gene in Drosophila melanogaster. Gene 229, 109-116.

NELSON, R. E., FESSLER, L. I., TAKAGI, Y., BLUMBERG, B., KEENE, D. R., OLSON, P. F., PARKER, C. G. and FESSLER, J. H. (1994). Peroxidasin: a novel enzyme-matrix protein of Drosophila development. EMBO J. 13, 3438-3447.

PERRIMON, N. and MAHOWALD, A. P. (1986). I(1)hopscotch, A larval-pupal zygotic lethal with a specific maternal effect on segmentation in Drosophila. Dev. Biol. 118, 28-41.

RAGONE, G., VAN DE BOR, V., SORRENTINO, S., KAMMERER, M., GALY, A.,
SCHENCK, A., BERNARDONI, R., MILLER, A. A., ROY, N. and GIANGRANDE, A. (2003). Transcriptional regulation of glial cell specification. Dev. Biol. 255, 138-150.

SEIPEL, K., GEORGIEV, O. and SCHAFFNER, W. (1992). Different activation domains stimulate transcription from remote ('enhancer') and proximal ('promoter') positions. EMBO J. 11, 4961-4968

SORRENTINO, R. P., CARTON, Y. and GOVIND, S. (2002). Cellular immune response to parasite infection in the Drosophila lymph gland is developmentally regulated. Dev. Biol. 243, 65-80.

SOUSTELLE, L. and GIANGRANDE, A. (2007a). Glial differentiation and the gcm pathway. Neuron Glia Biology 3, 5-16.

SOUSTELLE, L. and GIANGRANDE, A. (2007b). Novel gcm-dependent lineages in the postembryonic nervous system of Drosophila melanogaster. Dev. Dy namics 236, 2101-2108.

SOUSTELLE, L., JACQUES, C., ALTENHEIN, B., TECHNAU, G. M., VOLK, T. and GIANGRANDE, A. (2004). Terminal tendon cell differentiation requires the glide/gcm complex. Development 131, 4521-4532.

SOUSTELLE, L., ROY, N., RAGONE, G. and GIANGRANDE, A. (2008). Control o gcm RNA stability is necessary for proper glial cell fate acquisition. Molec. Cell. Neurosci. 37, 657-662.

SOUSTELLE, L., TROUSSE, F., JACQUES, C., CERON, J., COCHARD, P SOULA, C. and GIANGRANDE, A. (2007). Neurogenic role of Gcm transcription factors is conserved in chicken spinal cord. Development 134, 625-634.

TERMAN, J. R., MAO, T., PASTERKAMP, R. J., YU, H. H. and KOLODKIN, A. L. (2002). MICALs, a family of conserved flavoprotein oxidoreductases, function in plexin-mediated axonal repulsion. Cel/109, 887-900.

VINCENT, S., VONESCH, J. L. and GIANGRANDE, A. (1996). Glide directs glia fate commitment and cell fate switch between neurones and glia. Development 122, 131-139.

VOJTEK, A. B., HOLLENBERG, S. M. and COOPER, J. A. (1993). Mammalian Ras interacts directly with the serine/threonine kinase Raf. Ce//74, 205-214.

WANG, L., BROWN, J. L., CAO, R., ZHANG, Y., KASSIS, J. A. and JONES, R. S. (2004). Hierarchical recruitment of polycomb group silencing complexes. Molec. Cel/14, 637-646.

YOSHIDA, S., SOUSTELLE, L., GIANGRANDE, A., UMETSU, D., MURAKAMI, S., YASUGI, T., AWASAKI, T., ITO, K., SATO, M. and TABATA, T. (2005). DPP signaling controls development of the lamina glia required for retinal axon targeting in the visual system of Drosophila. Development 132, 4587-4598.

ZETTERVALL, C. J., ANDERL, I., WILLIAMS, M. J., PALMER, R., KURUCZ, E., ANDO, I. and HULTMARK, D. (2004). A directed screen for genes involved in Drosophila blood cell activation. Proc. Natl. Acad. Sci. USA 101, 14192-14197.

ZHAO, J. (2007). Sumoylation regulates diverse biological processes. Cell. Molec. Life Sci. $64,3017-3033$
5 yr ISI Impact Factor $(2008)=3.271$

\section{For all the latest on Pattern Formation research, see our latest Special Issue edited by C.-M. Chuong and M.K. Richardson.}

http://www.ijdb.ehu.es/web/contents.php?vol=53\&issue=5-6

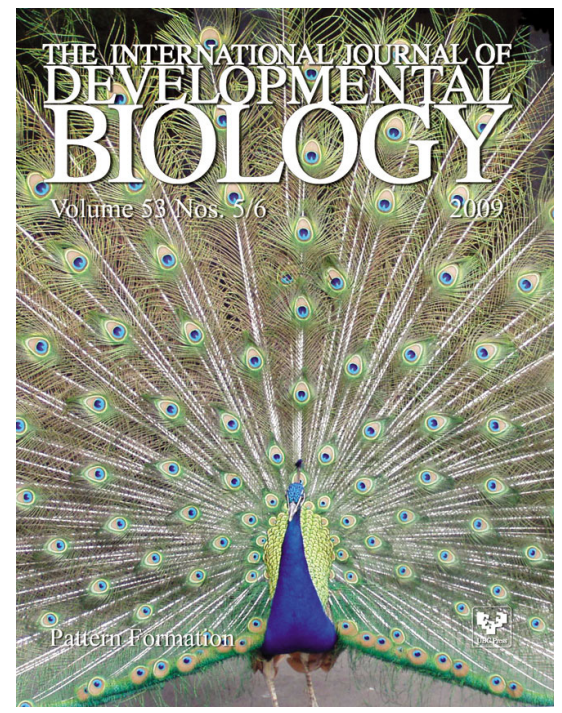




\section{Further Related Reading, published previously in the Int. J. Dev. Biol.}

See our recent Special Issue Fertilization, in honor of David L. Garbers and edited by Paul M. Wassarman and Victor D. Vacquier at: http://www.ijdb.ehu.es/web/contents.php?vol=52\&issue $=5-6$

PBX proteins: much more than Hox cofactors

Audrey Laurent, Réjane Bihan, Francis Omilli, Stéphane Deschamps and Isabelle Pellerin Int. J. Dev. Biol. (2008) 52: 9-20

The expression of MDP-1, a component of Drosophila embryonic basement membranes, is modulated by apoptotic cell death.

M Hortsch, A Olson, S Fishman, S N Soneral, Y Marikar, R Dong and J R Jacobs Int. J. Dev. Biol. (1998) 42: 33-42

Embryonic stem cells and transgenic mice in the study of hematopoiesis. S H Orkin

Int. J. Dev. Biol. (1998) 42: 927-934

Development and organization of glial cells in Drosophila melanogaster.

A Giangrande

Int. J. Dev. Biol. (1996) 40: 917-927

Drosophila differentiation genes instrumental in tumor suppression.

E Gateff, U Kurzik-Dumke, J Wismar, T Löffler, N Habtemichael, L Konrad, S Dreschers, $S$ Kaiser and U Protin

Int. J. Dev. Biol. (1996) 40: 149-156
5 yr ISI Impact Factor $(2008)=3.271$

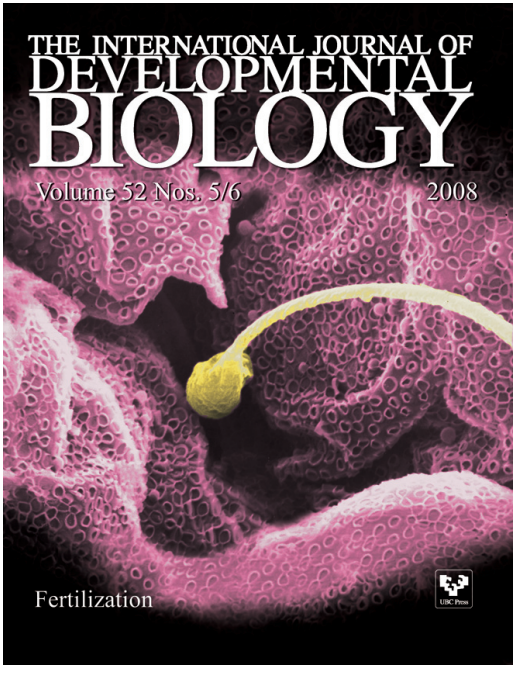

